\title{
EDITORIAL
}

\section{INTERRELATIONSHIP AND CROSS-FIELD RESEARCH IN FINANCIAL, HUMAN AND CAPITAL MARKETS}

Kaunas Faculty of Humanities, Vilnius University, (KHF, VU), Lithuania, organised the $1^{\text {st }}$ International and Interdisciplinary Scientific Conference on merging Physical Sciences, the Humanities and Social Sciences. The conference organiser was Kaunas Faculty of Humanities, Vilnius University together with the International Network of Young Researchers in Social Sciences - INYRSS (http:// www.inyrss.vukhf.lt) - and with welcome initiatives from St Gallen University (Switzerland) and Esperanto Association in Lithuania.

The conference was dedicated to fostering the dialogue between academicians, young researchers and practitioners on the impact of interdisciplinary in physical and social sciences and the humanities on the development, interpretation and presentation of transforming scientific knowledge and university studies. Our goal was to offer a conference programme, which balances between defenders and critics of interdisciplinary scientific research and university studies, adhering to strengthening the overall competitive advantage of institutional (universities and research bodies) governance.

Therefore the interdisciplinary approach was applied in Physical Sciences (Informatics) - represented by the acronym „FI" in the title of the conference, the Humanities (Philology) - the acronym ,HU“, and Social Sciences (Economics and Management) - the acronym ,SO“, which was sought to reflect the interrelationship and cross-field research issues in globalisation of economies, political and socio-economic realities, cultural-ethnic-linguistic crossroads, applications in business informatics, innovation management in the educational system.

His Excellency President of the Republic of Lithuania Mr. Valdas Adamkus expressed his worry about the situation of Social Sciences and the Humanities in Lithuania on the $4^{\text {th }}$ December, 2006 by seeking means and methods to prioritise these sciences in the context of planning and maintaining reforms in Lithuanian education and scientific research. Therefore the organisers of FIHUSO-2007 within the framework of governmental concern aspire to achieve the interdisciplinary dialogue amongst researchers, governmental bodies and business people by emphasising the need to enhance interdisciplinary research and cohesion of uni- versity multi-disciplinary studies based on universal, national, ethnic and societal values.

First International and Interdisciplinary Scientific Conference FIHUSO-2007 had also a strong background of national and international scientific conferences previously organised by individual departments at Kaunas Faculty of Humanities (Vilnius University). The thematic scope varied from business informatics to the development of economy, from texts and contexts to gender issues in the socio-cultural mindset. The united efforts of the Faculty produced a creatively new and holistically valid scientific approach to organising institutional conferences synergistically integrating fragmented pieces of scientific studies into a meaningful mosaic of multi-disciplinary, multi-lingual and multi-facet research.

With the attendance of over 200 participants, the FIHUSO-2007 papers were grouped in the following streams:

- STREAM A: Physical Sciences - Informatics (IT for business): e-learning and teaching of IT; information systems in financial markets, e-business, banking accounting, marketing; knowledge-based business IS, e-management systems.

- STREAM B: The Humanities - Linguistics \& Literature. Strategies for interpretative reading of literary texts: interdisciplinary approach; text and language; texts in contexts/contexts in texts; translation studies as an interdisciplinary object.

- STREAM C: The Humanities - Interlinguistics: linguistics in interdisciplinary perspectives: Ethno; Psycho-; Socio-; Inter-; Para-; Computer, etc.; research findings and discussions on Esperanto.

- STREAM D: Social Sciences - Economics. Sustainable development; labour market competitiveness; global innovation in financial services industry; regional economics; managing accounting systems.

- STREAM E: Social Sciences - Management. Knowledge management and competitive human resource; corporate social responsibility; IT applications in business; modern marketing applications; interdisciplinary business management studies. 
Members of FIHUSO-2007 scientific programme and conference participants came from 33 countries, namely: Australia, Austria, Belarus, Belgium, Brazil, China, Cyprus, Croatia, Czech Republic, Denmark, Egypt, Estonia, Finland, France, Germany, Hungary, Italy, Kazakhstan, Latvia, Lithuania, Netherlands, Norway, Poland, Russia, Serbia, Slovenia, Spain, Sweden, Switzerland, Turkey, Ukraine, the United Kingdom and the USA. We also welcomed a great number of senior researchers from Lithuanian universities (Vilnius Gediminas Technical University, Vytautas Magnus University, Kaunas University of Technology, Lithuanian University of Agriculture, Lithuanian Academy of Physical Education, Šiauliai University), governmental and municipal institutions and NGO (Kaunas County Tax Inspectorate, Lithuania; Kaunas Drama Theatre, Lithuania; Kaunas City Municipality, Lithuania; Forum for language rights and cultural diversity, Belgium) and business companies (JSC „Penkių kontinentu bankinès technologijos“, Lithuania; Coca-Cola HBC Lietuva; Arc-Kranj, Slovenia).

Quality papers from FIHUSO-2007 were carefully reviewed and selected for publication in the three international scientific journals, published by VU KHF, namely: 1) „Transformations in Business \& Economics“ (abstracted and indexed by a number of international scientific databases, including Thomson Services - ISI Web of Science); 2) „IJORTISS“ (International Journal of Research Trends in Social Sciences); 3) „Respectus Philologicus“ (abstracted and indexed by EBSCO database Humanities Index with full text). We also consider offering selected quality papers to other three journals, namely 4) "International Journal of Trade and Global Markets" (IJTGM, published by InderScience Ltd) and 5), Information Technologies and Control", published by Kaunas University of Technology, Lithuania, and 6) "Technological and Economic Development of Economy”, published by Vilnius Gediminas Technical University (Lithuania).

Therefore in this issue of "Technological and Economic Development of Economy", the focal object of the research papers lies in the interrelationship and cross-field research of financial, human and capital markets development, which directly impact the speed, quality and direction of economic development. It is of paramount importance that the contributors to this volume demonstrated in-depth efforts to investigate the economic development phenomenon in a number of economies in transition, namely Poland, Ukraine, Lithuania and China.

Assoc Prof Dr Dainora Grundey Chairperson of the Scientific Programme Committee and the Reviewers' Board of $1^{\text {st }}$ International and Interdisciplinary Scientific Conference FIHUSO-2007,

Vice-Dean for Scientific Research and International Relations

Kaunas Faculty of Humanities, Vilnius University, Muitinès g. 8, LT-44280 Kaunas, Lithuania, $<$ dainora.grundey@vukhf.lt> 